Revista Brasileira de Farmacognosia Brazilian Journal of Pharmacognosy 22(4): 850-853, Jul./Aug. 2012

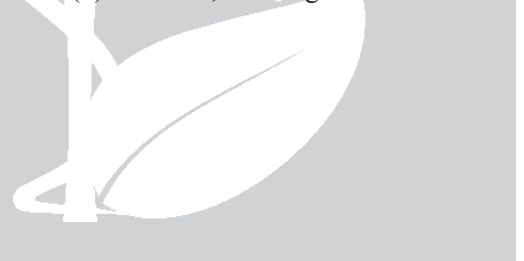

Article

Received 24 Nov 2011

Accepted 9 Jan 2012

Available online 24 May 2012

Keywords:

allelopathy

germination

inhibition

Plocamium brasiliense

halogenated monoterpenes

weeds

ISSN 0102-695X

http://dx.doi.org/10.1590/S0102-

$695 \times 2012005000065$

\section{Allelopathic potential of extracts the from marine macroalga Plocamium brasiliense and their effects on pasture weed}

\author{
Rainiomar Raimundo da Fonseca, ${ }^{1}$ Fredy A. Ortiz-Ramírez, ${ }^{2}$ \\ Diana N. Cavalcanti, ${ }^{2}$ Carlos José B. Ramos, ${ }^{3}$ Valéria L. \\ Teixeira, ${ }^{* 1,3}$ Antonio Pedro da Silva Sousa Filho ${ }^{4}$
}

${ }^{1}$ Programa de Pós-graduação em Química, Instituto de Química, Universidade Federal Fluminense, Brazil,

${ }^{2}$ Programa de Pós-graduação em Biologia Marinha, Instituto de Biologia, Universidade Federal Fluminense, Brazil,

${ }^{3}$ Departamento de Biologia Marinha, Universidade Federal Fluminense, Brazil,

${ }^{4}$ Embrapa/CPATU, Belém-PA, Brazil.

\begin{abstract}
Four extracts from the marine red alga Plocamium brasiliense (Greville) M.A.Howe \& W.R.Taylor were prepared to identify and characterize their potential allelopathic effects on seed germination, radicle elongation and hypocotyl development of the weeds Mimosa pudica L. and Senna obtusifolia (L.) Irwin \& Barneby. The four extracts were prepared in a sequence of solvents of increasing polarity: $n$-hexane, dichloromethane, ethyl acetate and ethanol/water (7:3). The germination bioassay was carried out at $25^{\circ} \mathrm{C}$ with a $12 \mathrm{~h}$ photoperiod and the radicle elongation and hypocotyl development at $25^{\circ} \mathrm{C}$ with a $24 \mathrm{~h}$ photoperiod. The dichloromethane extract showed inhibitory effects on seed germination of both plants (35 and 14\%, respectively, in M. pudica and S. obtusifolia), radical germination (52 and $41.7 \%$, respectively) and hypocotyl development (17.1 and $25.5 \%$, respectively). Given the high sensitivity of this parameter to the potential allelopathic effects and the insufficient number of references found in the literature, these results are expected to stimulate new tests with other species of marine algae. Given the high sensitivity of the method for the detection of allelopathic potential, the species $P$. brasiliense emerges as a possible source of allelopathic substances against weed species. The results are attributed to the chemical composition, especially in relation to the presence of halogenated monoterpenes.
\end{abstract}

\section{Introduction}

The inadequate use of fire and mowing, along with the application of synthetic herbicides, has become a very common practice for controlling weeds in Brazilian pastures. Nonetheless, these procedures have been demonstrated to be inefficient (Souza Filho et al., 2006). The synthetic herbicides currently utilized in agriculture have organochlorine and organophosphate chemicals in their composition. Thus, despite the importance of such herbicides for the control of invasive plants, there has been ample discussion concerning the damage they cause to both man and the environment.

Therefore, the investigation of the allelopathic potential of various living organisms might be a more viable alternative when it comes to controlling invasive plants. In fact, the liberation of chemical substances that have phytotoxic activities can have a significant influence on the population dynamics of plants in the countryside, since these substances may alter the pattern and the density of the vegetation (Souza Filho \& Alves, 2000, Souza Filho, 2002, Souza Filho et al., 2006; Souza et al., 2006). Taking this into consideration, our study aims to enable quantitative and qualitative improvements in the production of food on both small and large agricultural properties in Brazil.

In this context, Brazil has a large biological diversity, especially in marine environments, where macroalgae are especially relevant since they represent a natural strategic resource for the development of biotechnology. The genus Plocamium Lamouroux has approximately 42 species and more than 100 monoterpenes have been isolated from twelve species (Teixeira, 2009). P. brasiliense, the only species on the Brazilian coast, is distributed in North America, the Caribbean Islands 
(Taylor, 1960; Schneider \& Searles, 1991), Trinidad \& Tobago (Duncan \& Lee Lum, 2006) and South America (Taylor, 1930, 1960; Joly, 1957, 1965; Ganesan, 1990; Schneider \& Searles, 1991; Díaz-Pulido \& Díaz-Ruíz, 2003).

Previous studies of the chemical components isolated from Brazilian P. brasiliense have been performed by our group (Ferreira et al., 2010; Vasconcelos et al., 2010). The halogenated monoterpenes $\mathbf{1}, \mathbf{2}$ and $\mathbf{3}$ were isolated from $P$. brasiliense in a chemotaxonomic analysis (Vasconcelos et al., 2010). In another study, the crude $\mathrm{CH}_{2} \mathrm{Cl}_{2}$ extract (containing monoterpenes 1, 2 and 4) and a fraction enriched with the halogenated monoterpene $\mathbf{2}$ from $P$. brasiliense were evaluated for cytotoxicity and against the virus HSV-1 (Ferreira et al., 2010).<smiles>C=C[C@](C)(Cl)[C@@H](Cl)/C=C/C(=C\Cl)CCl</smiles>

1<smiles>CC(/C=C(\Br)[C@H](Cl)[C@](C)(Cl)/C=C/Br)=C\Br</smiles>

3<smiles>C[C@](Cl)(/C=C/Br)[C@H](Cl)/C=C/C(=C\Cl)C(Cl)Cl</smiles>

2

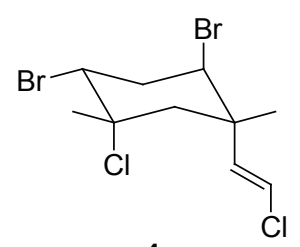

4
Studies showed that these metabolites represent a means of defense against marine herbivores, fouling organisms and pathogens, as well as protection against radiation and allopathic agents (e.g., Sakata et al., 1991). Based on these conclusions, the present study assesses the potential for allelopathic activity of four extracts (n-hexane, dichloromethane, ethyl acetate and aqueous ethanol) obtained from the marine alga Plocamium brasiliense (Rhodophyta).

\section{Materials and Methods}

\section{Plant material}

Specimens of Plocamium brasiliense (Greville) M.A.Howe \& W.R.Taylor were collected in October, 2010, in the sublittoral of Enseada do Forno, Armação de Búzios $(\mathrm{RJ})\left(22^{\circ} 45^{\prime} \mathrm{S}\right.$ e $\left.41^{\circ} 52^{\prime} \mathrm{W}\right)$. The seaweeds were washed with local seawater and separated from sediments, epiphytes and other associated organisms. The algae were dried for twenty days and extracted with the appropriate solvent. Voucher specimens were deposited in the Herbarium of the Universidade do Estado do Rio de Janeiro (HRJ 10331-32).

\section{Receptor species}

The receptor plants used in the bioassays were two of the main weeds that occur in areas of cultivated pastures in the Amazon region, which are known as malícia (Mimosa pudica) and mata-pasto (Senna obtusiloba). The seeds of these two plants were collected in the municipality of Castanhal-PA. The seeds were cleaned and purged and placed in seed conservation chambers. The seed dormancy was overcome as established by Souza Filho (2002) and Souza Filho et al. (2006).

\section{Preparation of crude extracts}

The algae $P$. brasiliense, collected and dried at room temperature (average of $28{ }^{\circ} \mathrm{C}$ ), were triturated in an industrial blender and placed in a plastic tray, yielding $5.16 \mathrm{~g}$ of powdered whole algae. The extracts were obtained by an exhaustive extraction using a decanting funnel $(1 \mathrm{~L})$. The procedures involved the sequential utilization of solvents of increasing polarity. Therefore, the order in which the solvents were used was: $n$-hexane, dichloromethane, ethyl acetate and ethanol/water (7:3). In the first step, $5.16 \mathrm{~g}$ of dry algae were placed in the decantation funnel with $400 \mathrm{~mL}$ of $n$-hexane for eight days. This process was repeated twice. The extracts were concentrated on a rotary evaporator, obtaining $122 \mathrm{mg}$ of n-hexane extractable material. The sequence of extraction was repeated for the other solvents, which generated the following masses: dichloromethane, $196 \mathrm{mg}$; ethyl acetate, $42 \mathrm{mg}$; and ethanol/water, $250 \mathrm{mg}$.

Assays

The seed germination bioassays were developed under controlled conditions of constant temperature $\left(25^{\circ} \mathrm{C}\right)$ and a photoperiod of $12 \mathrm{~h}$. Germination was monitored for fifteen days with daily counts and elimination of the germinated seeds. Germinated seeds were considered to be those that had a root length equal to or greater than $2.00 \mathrm{~mm}$ (Souza Filho, 2002, Souza Filho et al., 2006). Each transparent Petri dish, $9.0 \mathrm{~cm}$ in diameter, received twenty seeds. The radicle elongation biossays were performed under controlled conditions of constant temperature $\left(25^{\circ} \mathrm{C}\right)$ and a photoperiod of $24 \mathrm{~h}$ in a germination chamber with cool white fluorescent lamps and and a luminous flux of approximately $10 \mu \mathrm{mol} . \mathrm{m}^{-}$ ${ }^{2} \cdot \mathrm{s}^{-1}$. We used six seeds pre-germinated for approximately three days in a transparent Petri dish $9.0 \mathrm{~cm}$ in diameter. At the end of a period of ten days of growth, we measured the length of the radicles. Each Petri dish was covered with quantitative filter paper (Souza Filho, 2002).

A concentration of $1 \% \mathrm{~m} / \mathrm{v}$ of each crude extract was added at the beginning of each bioassay. Since then, only distilled water was added to the system when 
necessary. The test solutions were added only once, at the beginning of the bioassays, and thereafter distilled water added only when necessary.

\section{Statistical analysis}

The statistical test for all experiments was completely randomized with three repetitions. Data were submitted to the $\mathrm{F}$ test for analyses of variance, while the means were compared by the Tukey test $(p<5 \%)$. All analysis was performed with the program SAS for Windows (Sas, 1989).

\section{Results and Discussion}

The results for the effect of the crude extracts on the germination of $M$. pudica and S. obtusifolia are summarized in Table 1. No seaweed extract promoted a significant allelopathic effect on the seeds of $S$. obtusifolia, the best result (14\% of inhibition) being that of the dichloromethane extract. By comparison, the allelopathic effects of the extracts on $M$. pudica were more significant than those obtained with S. obtusifolia. The dichloromethane extract was the most active, with the greatest inhibition of the germination of the seeds $(25 \%)$.

Table 1. Inhibitory effects of the different crude extracts of the algae Plocamium brasiliense on the germination of two species of weeds. Data expressed as percentage of inhibition compared to the control.

\begin{tabular}{lcccc}
\hline \multirow{2}{*}{$\begin{array}{c}\text { Receptor } \\
\text { plants }\end{array}$} & $n$-hexane & dichloromethane & $\begin{array}{c}\text { ethyl } \\
\text { acetate }\end{array}$ & $\begin{array}{c}\text { ethanol/ } \\
\text { water }\end{array}$ \\
\cline { 2 - 5 } & $10.0 \pm 3.4$ & $25.0 \pm 5.4$ & $13.0 \pm 4.1$ & $14.0 \pm 2.7$ \\
$\begin{array}{l}\text { Mimosa } \\
\text { pudica }\end{array}$ & & & & \\
$\begin{array}{l}\text { Senna } \\
\text { obtusiloba }\end{array}$ & $4.0 \pm 1.3$ & $14.0 \pm 3.9$ & $6.0 \pm 2.6$ & $7.0 \pm 2.8$ \\
\hline
\end{tabular}

The analysis of the effect of each extract on radicle elongation is presented in Table 2 . The results show that the dichloromethane extract of $P$. brasiliense contains active components that inhibited 52.0 and $41.7 \%$, respectively, of the radicle elongation of $M$. pudica and $S$. obtusiloba. However, in the radicle elongation experiments, the ethyl acetate extract also showed $32.0 \%$ inhibition of $M$. pudica and $21.1 \%$ for S. obtusiloba. These expressive values in the radicle elongation bioassay demonstrate that the sensitivity to potential allelopathic effects is much greater in the radicle elongation phase than in seed germination.

In the analysis of the effect of each extract on hypocotyl development of the weeds, the ethanol/ water and dichloromethane extracts were more effective with S. obtusifolia than with M. pudica (Table 3). The dichloromethane extract was again the greatest inhibitor
(17.1\% for $M$. pudica and 25;5\% for S. obtusifolia), followed by the ethanol/water extract $(13.4 \%$ for $M$. pudica and $14.8 \%$ for $S$. obtusifolia). The crude dichloromethane extract was the most efficient and, therefore, the extract that represents the main source of secondary metabolites with allelopathic activity present in $P$. brasiliense. In addition, the $P$. brasiliense extracts tested were more efficient for $M$. pudica in the germination and radicle development bioassays, whereas $S$. obtusifolia showed better results in the hypocotyl experiment since it was more sensitive to the allelochemicals present in the dichloromethane and ethyl acetate extracts.

These results also indicate that the dichloromethane extract is more likely to inhibit the development of invasive plants than their germination, because the bioassay for radicle development presented results of greater magnitude.

Table 2. Inhibitory effects of the different crude extracts of the algae Plocamium brasiliense on the development of radicles. Data expressed as percentage of inhibition compared to the control treatment.

\begin{tabular}{lcccc}
\hline \multirow{2}{*}{$\begin{array}{c}\text { Receptor } \\
\text { plants }\end{array}$} & $n$-hexane & dichloromethane & $\begin{array}{c}\text { ethyl } \\
\text { acetate }\end{array}$ & $\begin{array}{c}\text { ethanol/ } \\
\text { water }\end{array}$ \\
\cline { 2 - 5 } & $11.6 \pm 5.4$ & $52.0 \pm 5.2$ & $32.0 \pm 4.4$ & $29.3 \pm 5.2$ \\
$\begin{array}{l}\text { Mimosa } \\
\text { pudica }\end{array}$ & & & \\
$\begin{array}{l}\text { Senna } \\
\text { obtusiloba }\end{array}$ & $8.4 \pm 2.8$ & $41.7 \pm 4.8$ & $21.1 \pm 3.9$ & $18.6 \pm 3.7$ \\
\hline
\end{tabular}

Table 3. Inhibitory effects of different crude extracts of the algae Plocamium brasiliense on the development of the hypocotyl. Data expressed as percentage of inhibition compared to the control treatment.

\begin{tabular}{lcccc}
\hline \multirow{2}{*}{$\begin{array}{c}\text { Receptor } \\
\text { plants }\end{array}$} & $n$-hexane & dichloromethane & $\begin{array}{c}\text { ethyl } \\
\text { acetate }\end{array}$ & $\begin{array}{c}\text { ethanol/ } \\
\text { water }\end{array}$ \\
\cline { 2 - 5 } & $8.7 \pm 3.1$ & $17.1 \pm 3.2$ & $10.4 \pm 2.8$ & $13.4 \pm 3.0$ \\
\hline $\begin{array}{l}\text { Mimosa } \\
\text { pudica }\end{array}$ & & & & \\
$\begin{array}{l}\text { Senna } \\
\text { obtusiloba }\end{array}$ & $6.4 \pm 2.7$ & $25.5 \pm 3.8$ & $9.8 \pm 3.0$ & $14.8 \pm 3.8$ \\
\hline
\end{tabular}

The results obtained with the extracts point to the importance of a search for the chemical components responsible for these phytotoxic activities. In any event, the red marine alga $P$. brasiliense can now be considered to be a potential source of herbicides.

\section{Acknowledgment}

We are grateful to the CNPq and FAPERJ for financial support and for Productivity Fellowships to VLT. DNC thanks the CNPq for providing PostDoctoral support and RRF and FAOR thank CAPES for DSc fellowships. 


\section{References}

Díaz-Pulido G, Díaz-Ruíz M 2003. Diversity of benthic marine algae of the Colombian Atlantic. Biota Colombiana 4: 203-246.

Duncan EJ, Lee Lum LM 2006. A checklist of the marine macroalgae of the Republic of Trinadad and Tobago. Caribbean Mar Studies 7: 1-96.

Ferreira WJ, Amaro R, Cavalcanti DN, Rezende CM, Giongo VA, Barbosa JE, Paixão ICNP, Teixeira, VL 2010. Antiherpetic activities of chemical components from the Brazilian red alga Plocamium brasiliense. Nat Prod Commun 5: 1167-1170.

Ganesan EK 1990. A catalog of benthic marine algae and seagrasses of Venezuela. Caracas: Fondo Editorial Conicit, p 1-237.

Joly AB 1957. Contribuição ao conhecimento da flora ficológica marinha da Baía de Santos e Arredores. Bol Fac Fil Ci Letras Univ S Paulo, Bot 14: 3-199.

Joly AB 1965. Flora marinha do litoral norte do estado de São Paulo e regiões circunvizinhas. Bol Fac FilCi Letras Univ S Paulo, Bot 21: 5-393.

Sakata K, Iwase Y, Ina K, Fujita D 1991. Chemical studies on feeding inhibitors for marine herbivores. 2. Halogenated terpenes isolated from the red alga Plocamium leptophyllum as fedding inhibitors for marine herbivores. Nippon Suisan Gakkaishi 57: 743-746.

SAS 1989. User's Guide. Version 6.12, SAS Inst. Inc., Cary, NC.

Schneider CW, Searles RB 1991. Seaweeds of the southeastern United States - Cape Hatteras to Cape Canaveral. Durrham \& London: Duke University Press, Durham, p 1-553.

Souza Filho APS, Alves SM 2000. Potencial alelopatico de plantas de acapu (Vouacapoua americana): efeitos sobre plantas daninhas de pastagens. Planta Daninha 18: 435-441.

Souza Filho APS, Santos RA, Santos LS, Guilhon GMP, Santos AS, Arruda MSP, Muller AH, Arruda AC 2006. Potencial alelopático de Myrcia guianensis. Planta Daninha 24: 649-656.

Souza Filho APS 2002. Atividade potencialmente alelopática de extratos brutos e hidroalcoólicos de feijão-de-porco (Canavalia ensiformis). Planta Daninha 20: 357-364.

Souza LS, Velini ED, Martins D, Rosolem CA 2006. Efeito alelopático de capim-braquiária (Brachiaria decumbens) sobre o crescimento inicial de sete espécies de plantas cultivadas. Planta Daninha 24: 657-668.

Taylor WR 1930. A synopsis of the marine algae of Brazil. Revue Algologique 5: 1-35.

Taylor WR 1960. Marine algae of the eastern tropical and subtropical coasts of the Americas. Ann Arbor, The University of Michigan Press, p 1-870.

Teixeira VL 2009. Produtos Naturais Marinhos. In Biologia Marinha. Pereira RC, Soares-Gomes A (Eds), Rio de Janeiro, Interciência, p 443-471.

Vasconcelos MA, Ferreira WJ, Pereira RC, Cavalcanti DN, Teixeira VL 2010. Chemical constituents from the red alga Plocamium brasiliense (Greville) M. Howe and W.R. Taylor. Biochem Syst Ecol 38: 119-121.

\section{*Correspondence}

Valéria Laneuville Teixeira

Departamento de Biologia Marinha, Instituto de Biologia, Universidade Federal Fluminense

Caixa Postal 100.644, 24097-100 Niterói-RJ, Brazil

gbmvalt@vm.uff.br

Tel. +552126292296

Fax: +552126292292 